\title{
Infectious hematopoietic necrosis virus antibody profiles in naturally and experimentally infected Atlantic salmon Salmo salar
}

\author{
Sophie St-Hilaire ${ }^{1,2, *}$, Carl S. Ribble ${ }^{1}$, Scott E. LaPatra ${ }^{3}$, Stacy Chartrand ${ }^{2}$, \\ Michael L. Kent ${ }^{2, * *}$ \\ ${ }^{1}$ Department of Population Medicine, University of Guelph, Guelph, Ontario N1G 2W1, Canada \\ ${ }^{2}$ Pacific Biological Station, Department of Fisheries and Oceans, Nanaimo, British Columbia V9T 1E1, Canada \\ ${ }^{3}$ Clear Springs Foods, Buhl, Idaho 83316, USA
}

\begin{abstract}
Atlantic salmon Salmo salar naturally and experimentally exposed to infectious hematopoietic necrosis virus (IHNV) in British Columbia, Canada, developed antibodies against the virus. More than $50 \%$ of the fish exposed to IHNV remained seropositive for several months after the IHN epizootic had subsided. The virus itself could not be detected in asymptomatic fish once the fish had recovered from IHN. The persistence of IHNV-specific antibodies in a large percentage of Atlantic salmon, from 4 different populations that survived an outbreak of IHN, and the lack of IHNVspecific antibodies in fish with no history of the disease, suggests that serology may be a useful tool for determining previous exposure to the virus. It may be important to determine whether Atlantic salmon have been infected with IHNV because, although the virus is difficult to detect in asymptomatic fish, an incidental finding suggests it may persist in a small number of fish after the outbreak has subsided. Furthermore, the presence of seropositive fish would be an indication that the virus may be enzootic at a farm, and such information would thus aid producers with stocking decisions.
\end{abstract}

KEY WORDS: IHNV - IHNV-specific antibodies · Surveillance - Convalescent carrier state · Atlantic salmon

Resale or republication not permitted without written consent of the publisher

\section{INTRODUCTION}

In 1992 the first case of infectious hematopoietic necrosis virus disease (IHN) was reported in Atlantic salmon Salmo salar while in salt water net-pens in British Columbia, Canada (Armstrong et al. 1993). Subsequently, a number of other outbreaks were reported in the same region. In 1996, the aquaculture industry in British Columbia implemented an area management plan designed to reduce farm to farm spread of this viral pathogen. One component of this

\footnotetext{
*E-mail: ssthilai@ovc.uoguelph.ca

${ }^{* *}$ Present address: Department of Microbiology, 220 Nash Hall, Center for Salmon Disease Research, Oregon State University, Corvallis, Oregon 97331-3804, USA
}

plan was to simultaneously fallow as many sites in the affected area as possible, and gradually re-introduce Atlantic salmon to the area. In order to gain a better understanding of the origin of this virus within the salt water net-pen industry, a surveillance program was initiated to monitor cultured fish for exposure to IHN virus (IHNV) as they were re-introduced to the previously affected sites.

The method traditionally used in Canada to monitor for IHNV has been virus isolation (Thorburn, 1996). This method is effective if the fish are undergoing an epizootic; however, if the population has recovered from IHN, it is difficult to the detect virus in the survivors (Thorburn 1996). Another method of monitoring for previous exposure to IHNV is via serological analysis (Hattenberger-Baudouy et al. 1989, 1995, LaPatra 
1996). Antibodies against IHNV were first reported in rainbow trout Oncorhynchus mykiss in the early 1970s (Amend \& Smith 1974). Subsequent studies, using natural and experimental bath exposure to IHNV in rainbow trout, revealed a strong antibody response within 6 wk (LaPatra et al. 1993) to 2 mo of exposure (Hattenberger-Baudouy et al. 1989, 1995). In addition, antibodies were detected in a large percentage of fish for several months after exposure to the virus (Hattenberger-Baudouy et al. 1989, LaPatra et al. 1993, Ristow et al. 1993). The long duration of IHNV-specific antibodies in trout populations infected with the virus, and the absence of these antibodies in non-infected fish, makes serological analysis a potentially useful tool (Hattenberger-Baudouy et al. 1989, 1995, LaPatra 1996).

A preliminary study done by LaPatra (1996) suggests that Atlantic salmon exposed to IHNV electropherotype 1 produce virus-specific antibodies. Serology may therefore be a useful tool in this species of fish. However, before this methodology could be used by the British Columbia aquaculture industry in their surveillance program, it had to be validated.

One of the objectives of this study was to describe the antibody profiles for Atlantic salmon after laboratory exposure to an IHNV isolate from British Columbia, Canada. The second objective was to determine whether the antibody profile of fish exposed to IHNV in a laboratory was consistent with what was observed in British Columbia when Atlantic salmon in salt water net-pen sites were naturally infected with the virus.

\section{MATERIAL AND METHODS}

Laboratory exposure experiment. Two separate groups of post-smolt ${ }^{1}$ Atlantic salmon (McConnell X Mowi strain) were used in this experiment, which was conducted at the Pacific Biological Station, in Nanaimo, British Columbia, Canada. Because the majority of Atlantic salmon in British Columbia after 1996 were vaccinated with an autogenous killed vaccine prior to salt water transfer, and the information from this study was to be used to develop a sampling protocol for an IHN surveillance program, we felt it was necessary to determine the antibody response to IHNV for both vaccinated and unvaccinated fish. The first group of fish in Tank 1A $(\mathrm{N}=157)$ and the control tank, Tank 1B $(\mathrm{N}=21)$, were vaccinated 2 mo prior to the experiment with an experimental killed autogenous IHNV vaccine. These fish were, on average, $57 \mathrm{~g}$

${ }^{1}$ This term refers to fish that have undergone the process of smoltification
( $\mathrm{n}=5, \mathrm{SD}=9.9$ ). The second group of fish was not vaccinated, and was held in Tank $2 \mathrm{~A}(\mathrm{~N}=380)$ and Control Tank 2B $(\mathrm{N}=18)$, with an average weight of $40.3 \mathrm{~g}$ ( $\mathrm{n}=5, \mathrm{SD}=7.28)$.

Five fish from each challenge tank were sampled prior to exposure to IHNV. These fish were euthanized and blood was collected for IHNV antibody analysis using the $50 \%$ plaque reduction test described in LaPatra et al. (1993). Two modifications were made to the protocol: the cell monolayer was not pretreated with $7 \%$ polyethylene glycol, and the cell culture plates were incubated at $15^{\circ} \mathrm{C}$ instead of $18^{\circ} \mathrm{C}$.

The anterior kidney of each of the 10 fish was removed aseptically and tested for IHNV by virus isolation, as described in Traxler et al. (1997). The only modifications to the protocol used by Traxler et al. (1997) were that the overlay used in this study did not contain $1 \%$ methyl cellulose, and viral titres were not calculated.

The remainder of the fish in Tanks $1 \mathrm{~A}$ and $2 \mathrm{~A}$ were exposed to IHNV in separate static baths ( 255 1 for Tank $1 \mathrm{~A}$ and $350 \mathrm{l}$ for Tank $2 \mathrm{~A}$ ) for $1 \mathrm{~h}$ at a concentration of $10^{2}$ plaque-forming units (pfu) $\mathrm{ml}^{-1}$ of water. The virus used in this study was an isolate collected from Atlantic salmon in British Columbia in 1992. After $1 \mathrm{~h}$ the water flow was returned to approximately $10 \mathrm{l}$ $\min ^{-1}$. All tanks were maintained on a single pass ambient salt water flow through system. The control tanks had a volume of 2001 , and the exposure tanks had a volume of $760 \mathrm{l}$. All fish were fed to satiation once a day with a commercially prepared feed.

Fish in all 4 tanks were monitored for $47 \mathrm{wk}$. Dead fish were removed on a daily basis and a post-mortem was performed on all fish that died during this period. All the dead fish from Tanks 1B and 2B (control tanks) were tested for IHNV by virus isolation. At the end of the study all remaining fish in Tanks $1 \mathrm{~B}$ and $2 \mathrm{~B}$ were tested for IHNV-specific antibodies.

Due to the large number of fish that died within the first $6 \mathrm{wk}$ of the study in the IHNV-exposed tanks (1A and $2 \mathrm{~A}$ ), only $91 \%$ of the fish that died in Tank $1 \mathrm{~A}$ and $60 \%$ of the fish that died in Tank 2A were tested for IHNV by virus isolation. To confirm IHNV in these tanks, 4 of the positive virus assays (3 fish were from Tank 2A and 1 fish was from Tank 1A) were tested with a nested RT-PCR test using primers for the nucleocapsid (N) gene (see below). Once IHNV was confirmed in both tanks, fish that died within 6 wk of exposure to the virus were considered infected with IHNV based on the results of virus isolation only. However, all fish that died $6 \mathrm{wk}$ after exposure to IHNV in Tanks 1A and 2A were tested by virus isolation and all positive virus assays were confirmed by RT-PCR.

Antibody response and persistence of IHNV in asymptomatic fish: Atlantic salmon in Tanks 1A and 
2A were sampled on a periodic basis to test for both IHNV and IHNV-specific antibodies. Every 3 to 5 d, for the first $9 \mathrm{wk}$ of the experiment, 3 to 10 fish per tank were euthanized. Blood was collected from the caudal vein of the fish for antibody analysis using the $50 \%$ plaque reduction technique. After $9 \mathrm{wk}$, samples were collected less frequently to ensure there were enough fish for the remainder of the experiment. All surviving fish were euthanized after $47 \mathrm{wk}$ and tested for the presence of IHNV-specific antibodies using the $50 \%$ plaque reduction technique.

A post-mortem was done on all euthanized fish that were sampled for IHNV-specific antibodies. The anterior kidney was removed aseptically from each fish, and tissues were tested by virus isolation. If tissues were not tested within 24 to $36 \mathrm{~h}$ after collection, they were stored at $-80^{\circ} \mathrm{C}$ until they could be evaluated. The first fish in each tank to test positive for IHNV by viral isolation was also tested with a nested RT-PCR test specific to the virus.

Field study. Blood samples were collected and tested for IHNV-specific antibodies from fish on 2 sites where the fish had experienced an IHN epizootic (Sites M and N), and 2 sites with no known history of IHN (Sites Z and Q). Infectious hematopoietic necrosis virus had been confirmed on Sites $\mathrm{M}$ and $\mathrm{N}$ prior to this study by virus isolation and confirmed by RT-PCR. The producers from Sites $\mathrm{Z}$ and $\mathrm{Q}$ were questioned regarding the disease history of their site, and reported no signs of IHN. Furthermore, records from both sites were examined to determine whether there were any unexplained spikes in mortality.

The prevalence of IHNV-specific antibodies was determined for 2 harvests of Atlantic salmon from Site M. Both sets of samples were collected (within 1 mo of one another) approximately 1 yr after the peak of a second outbreak of IHN. The prevalence of IHNVspecific antibodies was determined for 1 harvest of fish from Site N, approximately 1 yr after an initial outbreak of IHN and 6 wk after a second outbreak on this site.

Blood was collected on the processing line during harvests, by heart puncture after the fish were stunned with carbon dioxide gas. Fish were sampled by a convenience sampling method: as one fish was completed the next fish in line was bled. The number of fish sampled varied from 40 to 94 , depending on the time available. The total number of fish in a harvest ranged from 3000 to 6000 . Blood was collected in $3 \mathrm{ml}$ vacutainer tubes with no additive (Bectin Dickinson, Franklin Lakes, NJ) using 11/2 inch (ca $3.81 \mathrm{~cm}) 22$ gauge needles (Bectin Dickinson). Samples were kept on ice until they were brought back to the laboratory where they were allowed to clot at $4^{\circ} \mathrm{C}$. Within $24 \mathrm{~h}$ after collection the blood was centrifuged at $1500 \times g$ for $10 \mathrm{~min}$ at $4^{\circ} \mathrm{C}$.
Serum was removed and stored at $-20^{\circ} \mathrm{C}$ until it could be evaluated for antibodies using the $50 \%$ plaque reduction technique.

From 2 of the harvests, one from Site $\mathrm{M}$ and the other from Site N, 48 fish were also sampled for virus isolation to determine the prevalence of IHNV. Again, fish were collected by a convenience sampling method. Fish were sampled off the processing line after the body cavity had been opened but before the visceral organs had been removed. The fish tested for virus isolation were not the same fish as those tested for IHNVspecific antibodies; however, they were from the same harvests. The anterior kidney of individual fish was removed aseptically and placed into individual sterile plastic bags. Samples were maintained on ice until they were brought back to the laboratory where they were either tested by viral isolation within 24 to $36 \mathrm{~h}$ or frozen at $-80^{\circ} \mathrm{C}$ for later evaluation. The protocol followed for viral isolation was identical to that described in the laboratory exposure experiment.

Nested RT-PCR protocol. RNA extraction: Two hundred $\mu \mathrm{l}$ of cell culture media was placed in a $1.5 \mathrm{ml}$ centrifuge tube (Life Technologies, Burlington, ON) and $900 \mu \mathrm{l}$ of Trizol (Life Technologies) was added to the tube. After incubating at room temperature for $5 \mathrm{~min}, 200 \mu \mathrm{l}$ of chloroform was added to the tube. The mixture was vortexed, incubated at room temperature for $5 \mathrm{~min}$ and centrifuged at $12000 \times g$ for $8 \mathrm{~min}$. The aqueous phase was transferred to a new $1.5 \mathrm{ml}$ centrifuge tube containing $500 \mu \mathrm{l}$ of isopropanol. After $5 \mathrm{~min}$ at room temperature the mixture was centrifuged at $12000 \times g$ for $5 \mathrm{~min}$. The isopropanol was decanted and $750 \mu \mathrm{l}$ of $75 \%$ ethanol was added to the mixture, vortexed and centrifuged at $7500 \times g$ for $5 \mathrm{~min}$. The alcohol was decanted and the pellet was allowed to dry for $10 \mathrm{~min}$. Thirty $\mu \mathrm{l}$ of ribonuclease-free water was added to the tubes and heated at $55^{\circ} \mathrm{C}$ for $10 \mathrm{~min}$ to dissolve the RNA pellet.

Nested reverse transcriptase polymerase chain reaction: The following protocol was obtained from Dr W. Batts at the Western Fisheries Research Center, United States Geological Survey, Biological Resource Division, Seattle, WA, USA (1997). The SuperscriptRT system (Life Technologies) was used to make a master mix which consisted of $25 \mu \mathrm{l} 2 \times$ buffer, $0.1 \mu \mathrm{l}$ Rnase inhibitor, RT/Taq $1 \mu \mathrm{l}, 17.9 \mu \mathrm{l}$ Rnase-free water, and $0.5 \mu \mathrm{l}$ of the 2 first primers (IHNV N $88[+]$ [nt $88-$ 105: AAG GGG GGA GTC CTC GAG] and IHNV N 969[-] [nt 969-951: CCT ATC GTT GAT GTT CAT G]). Forty-five $\mu \mathrm{l}$ of this mix were combined with $5 \mu \mathrm{l}$ of the test RNA sample in a PCR tube (Life Technologies). The DNA Engine Peltier Thermal Cycler Model PTC-200 (MJ Research, Inc., Watertown, MA, USA) was used for DNA transcription and amplification. The sample was then placed in a preheated block 
$\left(50^{\circ} \mathrm{C}\right)$ to allow for reverse transcription to take place. After 20 min the block was heated to $95^{\circ} \mathrm{C}$ for $2 \mathrm{~min}$ (initial denaturing). Then the block went through 30 cycles of $95^{\circ} \mathrm{C}$ for $30 \mathrm{~s}, 50^{\circ} \mathrm{C}$ for $30 \mathrm{~s}$, and $72^{\circ} \mathrm{C}$ for $60 \mathrm{~s}$. After these cycles the block was heated to $72^{\circ} \mathrm{C}$ for $7 \mathrm{~min}$ and cooled to $4^{\circ} \mathrm{C}$.

For the second amplification step another master mix was made containing $10 \mu \mathrm{l}$ of buffer with $1.5 \mathrm{mM}$ $\mathrm{MgCl}_{2}, 10 \mu \mathrm{l} 2 \mathrm{mM}$ dNTP, $0.25 \mu \mathrm{Taq}, 25.75 \mu \mathrm{l}$ of Rnase-free water, and $0.5 \mu \mathrm{l}$ of the 2 primers (IHNV N 2410 [+] [nt 361-380: TTC GCA GAT CCC AAC AA] and IHNV N 683 [-] [nt 683-666: GCG CAC AGT GCC TTG GCT]; Life Technologies). Forty-seven $\mu$ of this mixture were combined with $3 \mu$ of the sample from the first PCR amplification step in a fresh PCR tube. The tube was placed in the block and the following program was run: $95^{\circ} \mathrm{C}$ for $3 \mathrm{~min}$ followed by 30 cycles of $95^{\circ} \mathrm{C}$ for $30 \mathrm{~s}, 53^{\circ} \mathrm{C}$ for $30 \mathrm{~s}$, and $72^{\circ} \mathrm{C}$ for $60 \mathrm{~s}$. After the last cycle the block is maintained at $72^{\circ} \mathrm{C}$ for $7 \mathrm{~min}$ and then cooled to $4^{\circ} \mathrm{C}$. The sample was then electrophoresed in $1.5 \%$ agarose.

Statistical analysis. The weekly prevalence of seropositive fish in Tanks $1 \mathrm{~A}$ and 2A was calculated by summing up the total number of seropositive fish tested during the week and dividing the sum by the number of fish tested. A 95\% confidence interval was calculated for each estimated proportion using Sterne's exact limits (Santner \& Duffy 1980).

A fish was considered positive if it had an antibody titre greater than or equal to 20. Antibody titres were reported as the inverse of the highest serum dilution that resulted in a $50 \%$ reduction in the average number of plaques found in the negative control. The lowest dilution tested was 1:20 and the highest was 1:160.

The weekly mortality rates for the Atlantic salmon in our laboratory exposure study were calculated separately for Tanks $1 \mathrm{~A}$ and 2A by summing the total number of dead individuals for each week and dividing that sum by the population at risk at the beginning of the week, minus half of the withdrawals (from sampling) that occurred each week (Martin et al. 1987). Weekly mortality rates were expressed as percentages and plotted over time using Excel (Windows 97, Microsoft, Seattle, WA).

The prevalence of IHNV and IHNV-specific antibodies for each group of fish collected in the field study was calculated by dividing the number of positive samples by the total number tested. A fish was considered positive for IHNV based on viral assay results alone. As in the laboratory experiment, a fish was considered seropositive if it had an antibody titre greater than or equal to 20. A $95 \%$ confidence interval was calculated using the exact binomial method (Daniel, 1987) and the computer program EpiInfo 6.0 (Center for Disease Control, Atlanta, GA).

\section{RESULTS}

\section{Lab exposure experiment}

The 5 fish from each of the tanks tested prior to IHNV exposure were negative for both IHNV and IHNV-specific antibodies (titer <20). Mortality associated with IHNV began within $10 \mathrm{~d}$ of exposure in Tank 1A, and within $3 \mathrm{~d}$ in Tank 2A. Infectious hematopoietic necrosis virus was confirmed in both tanks by the RT-PCR. The mortality curve after fish were exposed to IHNV peaked at 2 and $3 \mathrm{wk}$ post-exposure in both tanks. By 6 wk post-exposure the disease outbreak had subsided (Figs $1 \& 2$ ). During the first $6 \mathrm{wk}$ of the experiment, $94 \%$ of the dead fish in Tank $1 \mathrm{~A}$ and $65 \%$ of the dead fish in Tank 2A tested positive for IHNV by virus isolation. Sixteen of the 50 fish that died in Tank $2 \mathrm{~A}$ within $10 \mathrm{~d}$ of exposure to IHNV, and were tested for IHNV, had erosions on their body wall consistent with a salt water Cytophaga sp. bacterial infection (Kent et al. 1988). Fourteen of these 50 fish had signs consistent with poor smoltification (parr marks on the lateral body).

A second spike in mortality occurred in Tank 2A approximately $5 \frac{1}{2}$ mo after initial exposure to the virus (Fig. 2). This increase in mortality was attributed to an outbreak of piscirickettsial septicemia ${ }^{2}$ (Almendras \& Fuentealba 1997), but virus was also isolated from 2 of the 28 fish that died between 23 and 33 wk post-exposure, and both fish were confirmed IHNV positive by RT-PCR. Fish in Tank 1A did not have an outbreak of piscirickettsial septicemia. Only 6 fish died in this tank between 6 and 47 wk post exposure, and none of these fish tested positive for virus.

The cumulative mortality for $47 \mathrm{wk}$ in Control Tanks $1 \mathrm{~B}$ and $2 \mathrm{~B}$ was $23.8 \%(5 / 21)$ and $27.8 \%$ (5/18), respectively. Four of the 5 control fish that died in Tank 1B died after the water flow was accidentally turned off to this tank. The fish that died in Tank 2B had erosions on their body walls consistent with a Cytophaga sp. bacterial infection. All control fish that died $(\mathrm{n}=10)$ were negative for IHNV by viral isolation and, at the end of the study, all remaining fish in the control tanks ( $\mathrm{n}=$ 29) were negative for IHNV-specific antibodies.

\section{Antibody response and persistence of IHNV in asymptomatic fish}

The antibody profiles determined for Tanks $1 \mathrm{~A}$ and 2A were similar despite the differences in the vaccina-

\footnotetext{
${ }^{2}$ This was diagnosed by microscopic examination of liver imprints with Gram stain
} 


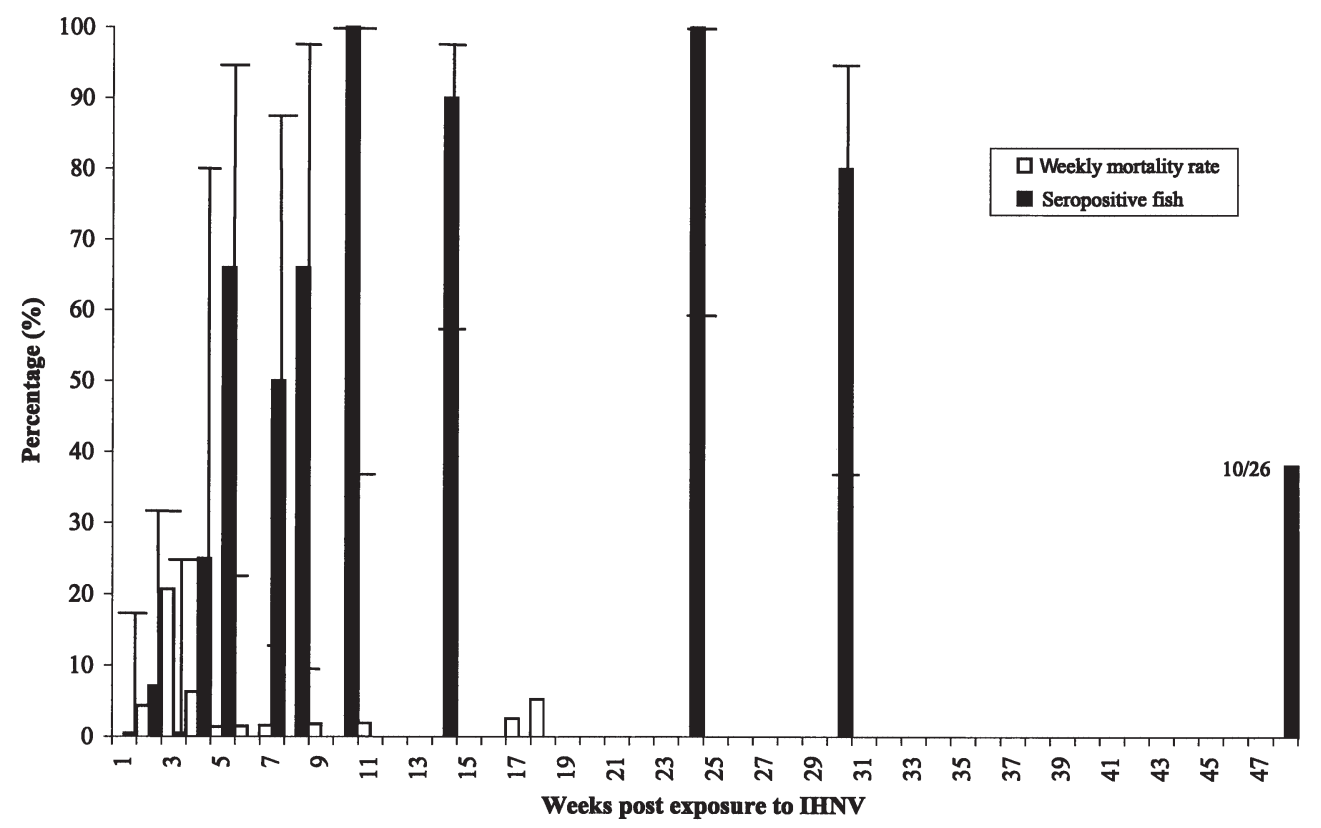

Fig. 1. Weekly mortality rate and percent of seropositive Atlantic salmon in Tank $1 \mathrm{~A}$ after a bath exposure to IHNV at a concentration of $10^{2}$ plaque forming units $\mathrm{ml}^{-1}$ of water (bars indicate $95 \%$ CI for the seroprevalence estimate)

tion status, size, and general health of the fish (Figs 1 \& 2). The first fish to test seropositive from Tanks $1 \mathrm{~A}$ and 2A were detected 12 and 9 d post-exposure, respectively (Figs $1 \& 2$ ). The percent of seropositive fish in the samples collected from Tanks $1 \mathrm{~A}$ and $2 \mathrm{~A}$, within 5 wk of exposure, was low: $11 \%(6 / 54 \mathrm{SD}=0.32)$ in Tank $1 \mathrm{~A}$ and $9.1 \%(4 / 44 \mathrm{SD}=0.29)$ in Tank $2 \mathrm{~A}$. However, between 6 and 30 wk post-exposure, 86.2\% (25/29 SD $=0.35$ ) of the fish sampled from Tank $1 \mathrm{~A}$ and $90.6 \%$ $(29 / 32 \mathrm{SD}=0.30)$ of the fish sampled from tank $2 \mathrm{~A}$ had
IHNV-specific antibodies. All fish with antibodies, between 6 and 30 wk post-exposure, had titres greater than 160, whereas only 4 of the 10 seropositive fish detected before 5 wk post-exposure had antibody titres greater than 40 . In the last samples, taken at 47 wk post-exposure, $38 \%(10 / 26)$ of the fish in Tank $1 \mathrm{~A}$ and $81.8 \%(9 / 11)$ of the fish in Tank $2 \mathrm{~A}$ had IHNVspecific antibodies.

Of the fish euthanized for serological analysis within $6 \mathrm{wk}$ of exposure to IHNV, 48.9\% (23/47) of the fish
Fig. 2. Weekly mortality rate and percent of seropositive Atlantic salmon in Tank 2A after a bath exposure to IHNV at a concentration of $10^{2}$ plaque forming units $\mathrm{ml}^{-1}$ of water (bars indicate $95 \%$ CI for the seroprevalence estimate)

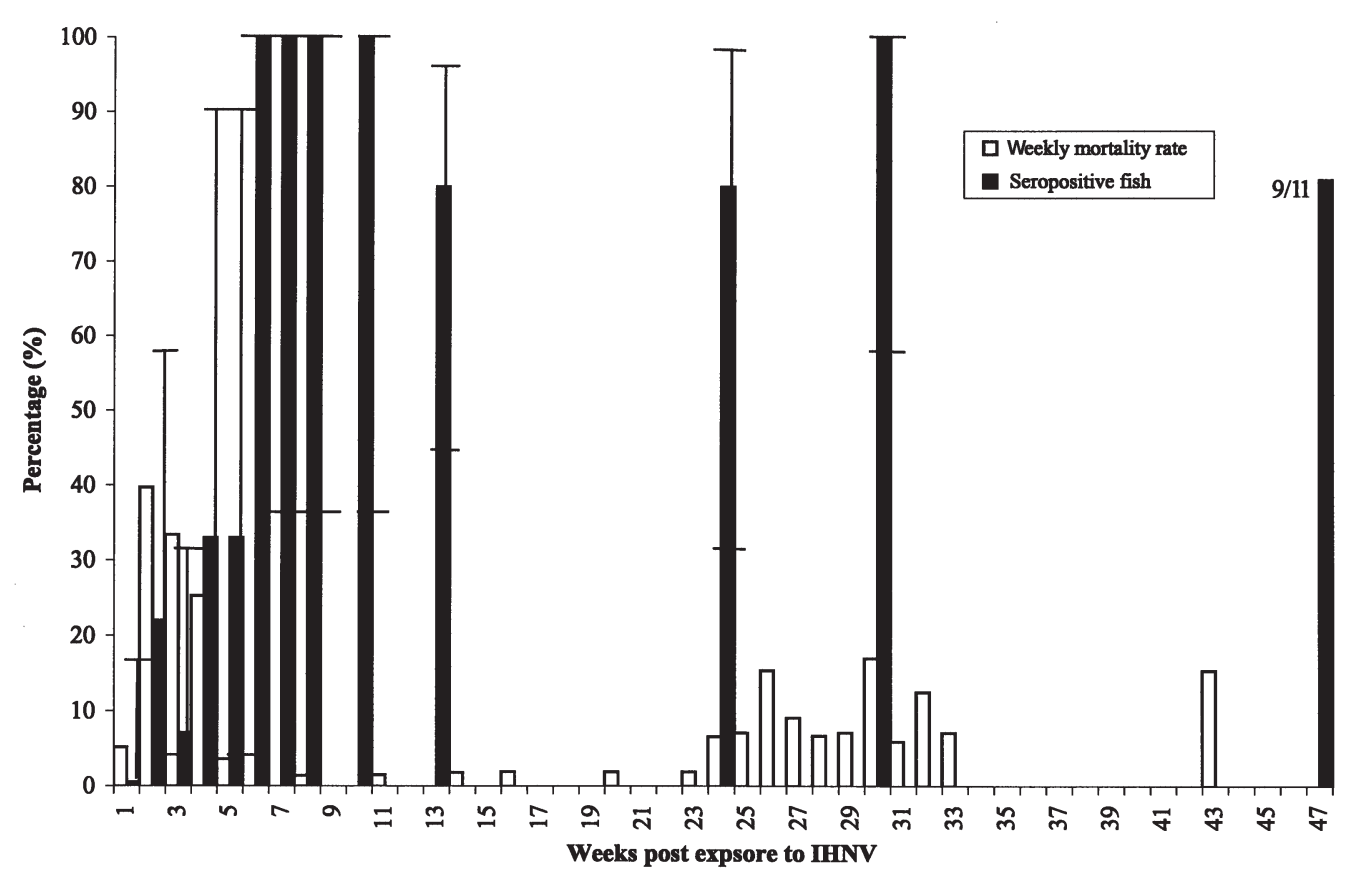


sampled from Tank $1 \mathrm{~A}$ and $55 \%(22 / 40)$ of the fish from Tank 2A tested positive for virus. Infectious hematopoietic necrosis virus was not detected in fish that were euthanized from either Tank $1 \mathrm{~A}$ or $2 \mathrm{~A}, 6 \mathrm{wk}$ or more after exposure to the virus $(n=58)$.

\section{Field study}

The 48 Atlantic salmon tested from Site N at the processing plant $1 \mathrm{yr}$ after the IHN outbreak on this farm were negative for IHNV by virus isolation (95\% CI: 0 , 7.4). In the same harvest, $77.7 \%(95 \% \mathrm{CI}: 67.9,85.6)$ of the fish tested had IHNV-specific antibody titres (Table 1). Of the 73 seropositive fish, 67 had a titre greater than 160 .

One year after the peak of the second outbreak of IHN on Site M, $80 \%$ (95\% CI: 64.4, 90.0) of the fish tested in 1 harvest had antibodies specific for IHNV (Table 1). All but 2 of these fish had a titre equal to or greater than 160. One month later, $66 \%$ (95\% CI: 51.7 , 78.5) of the fish tested were seropositive, and all but 2 of these fish had a titre above 160 . From the same harvest, 48 other fish were tested for virus and all were negative for the virus (95\% CI: 0, 7.4) (Table 1). No IHNV-specific antibodies were detected in the fish sampled from Site $Q$ or Z (Table 1). There was no unexplained mortality reported from either of these farms that suggested they had had IHN.

\section{DISCUSSION}

The findings from this study confirm LaPatra's findings (1996) that Atlantic salmon produce IHNV-specific antibodies when infected with the virus. Furthermore, a large percentage of the fish that survive an outbreak of IHN remain seropositive for a long period of time after the virus is no longer detectable in the population. This finding was consistent for fish ex-

Table 1. Summary of field data on Atlantic salmon collected from Sites $M$ and N with a history of IHN (date of onset of IHN outbreak: Site M, February 1996 and January 1997; and Site N, February 1996 and December 1996), and Sites Q and Z with no history of IHN. -: no samples taken

\begin{tabular}{|lccc|}
\hline Farm & $\begin{array}{c}\text { Date } \\
\text { collected }\end{array}$ & $\begin{array}{c}\text { Viral assay } \\
\text { at harvest (\%) }\end{array}$ & $\begin{array}{c}\text { Antibody } \\
\text { assay (\%) }\end{array}$ \\
\hline Site N & Dec 1,1997 & $0(0 / 48)$ & $77.7(73 / 94)$ \\
Site M & Feb 4,1997 & & $80(32 / 40)$ \\
& Mar 23,1997 & $0(0 / 48)$ & $66(35 / 53)$ \\
Site Z & Aug 21,1998 & - & $0(0 / 59)$ \\
Site Q & Oct 11, 1998 & - & $0(0 / 53)$ \\
\hline
\end{tabular}

posed to IHNV in a laboratory setting and under field conditions, which suggests that, in lieu of a disease history, serological analysis may be used effectively to determine if Atlantic salmon have been exposed to IHNV.

The antibody profile for fish in Tanks $1 \mathrm{~A}$ and 2A were similar, despite the difference in mortality rates, vaccination status, size, and general health of the fish (Figs 1 \& 2). In both tanks the prevalence of seropositive fish increased as the mortality rate associated with the virus decreased (Figs $1 \& 2$ ), approximately 5 to $6 \mathrm{wk}$ after exposure. After this time, the prevalence of fish with IHNV-specific antibody titres remained high throughout the study. Even $47 \mathrm{wk}$ after the initial exposure to the virus, when the study was terminated, the prevalence of fish in the remaining population with antibodies was still greater than $38 \%(10 / 26)$.

The samples collected from fish in salt water netpens were consistent with our laboratory findings. Infectious hematopoietic necrosis virus antibodies were only detected in fish that had a history of IHN. A high prevalence of seropositive fish were also detected well after the initial IHN outbreak had subsided on sites with a history of the disease (Table 1).

There may be concern that antibodies not specific for IHNV could lead to misclassification of the viral exposure status in some groups of fish (false positives). The closest related virus to IHNV and, therefore, the most likely to have an antibody that would cross react with IHNV is viral hemorhagic septicemia virus (VHSV), another piscine rhabdovirus. A study by VestergaardJørgensen et al. (1991) assessed the amount of crossreaction between the rainbow trout antibodies for these 2 viruses. They found positive IHNV antibody and VHSV antibody sera did not cross react with either virus when tested with the plaque reduction test. We found that non-specific antibodies in sera of fish with no known exposure to IHNV did not neutralize the virus (i.e., the experimental control tank fish, and fish from Sites Q and Z).

Our findings suggest that the presence of IHNV-specific antibodies in an Atlantic salmon population is a good indicator of previous infection with IHNV. This may be useful in lieu of our inability to detect virus in asymptomatic fish once an IHN outbreak had subsided. We were unable to isolate IHNV in asymptomatic fish once the IHN epizootic had subsided in both Tanks $1 \mathrm{~A}$ and $2 \mathrm{~A}$, and on the 2 salt water net-pen sites, $\mathrm{M}$ and N. Similar findings have been reported in rainbow trout that have recovered from the disease (Traxler et al. 1993, Hattenberger-Baudouy et al. 1995).

Knowing whether populations of Atlantic salmon have previously been infected with IHNV provides important information for farm managers. First, this 
knowledge can be used to determine the presence or absence of the virus in a given location. Thus, Atlantic salmon could be used as sentinels to indicate the effectiveness of disease control strategies. Second, if some survivors of IHN remain infected with the virus, as is suspected to occur in other species of salmonids such as rainbow trout (Amend 1975, Drolet et al. 1995, Bootland \& Leong 1999), sockeye salmon Oncorhynchus nerka (Mulcahy et al. 1984) and chinook salmon $O$. tshawytscha (St-Hilaire 2000), identification of IHN survivors could help producers prevent cohabiting naïve fish with potentially infected fish.

Reports of re-emergence of IHNV in both rainbow trout and sockeye salmon have occurred when the fish undergo sexual maturation (Amend 1975, Mulcahy et al. 1984). In the latter species, some researchers believe that fish are re-infected when they return to spawn in fresh water (Amos et al. 1989), or that there is a marine reservoir (Traxler et al. 1997). It is possible that a number of different scenarios occur, which would account for the inconsistency in the data reported in the literature, and the different hypotheses generated to explain these data.

The fact that we were able to isolate the virus from 2 out of 28 fish in Tank 2A that died 51/2 mo after the initial exposure to the virus supports the hypothesis that virus may persist in some fish after they have recovered from the viral disease. It is possible that the fish in Tank 2A remained infected with the virus because they were in poor general health. They suffered from co-infections with Cytophaga sp. and were not all ready for salt water transfer at the beginning of the experiment. Furthermore, they were diagnosed with Piscirickettsia salmonis subsequent to their recovery from IHN, which may have further compromised their ability to clear the virus. Nonetheless, the scenario observed in Tank 2A is not unlike what occurs under field conditions, and therefore, this incidental finding should be further investigated.

It is unlikely that the fish in Tank $2 \mathrm{~A}$ were reexposed to IHNV from an outside source, given that all control fish that died were negative for IHNV by virus isolation, and the control fish that survived did not have IHNV-specific antibodies. To determine whether there was a low level waterborne re-exposure to IHNV during the piscirickettsia outbreak, which may have only affected sick fish, 15 fish that died from Piscirickettsia salmonis and had been maintained on the same water supply as the experimental fish (for a different study) were tested for IHNV. No virus was found in these fish. It is, therefore, unlikely that IHNV was reintroduced into the experimental tank via the water supply during the piscirickettsial outbreak.

It is also unlikely that the Atlantic salmon were reexposed to IHNV via the water as the fish were held on salt water for the duration of the study. Although IHNV has been demonstrated to survive in salt water for a few weeks (Toranzo \& Hetrick 1982), it is rarely detected in fish during their salt water migration period (Bootland \& Leong 1999). Furthermore, in the last $10 \mathrm{yr}$, IHNV has never been detected in control fish at the Pacific Biological Station in many experiments that we have conducted with Atlantic salmon held in both fresh and salt water.

Additional work is required to confirm whether IHNV can persist in populations of Atlantic salmon and assess the potential risk of IHN survivors as a reservoir of the virus. The difficulty in studying the potential carrier state of IHNV is that it is difficult to detect using the diagnostic tools currently available. Perhaps stress testing previously exposed fish, as was inadvertently done in this study, or cohabiting previously exposed fish with naïve fish could help confirm whether persistent infections with IHNV occur, and whether these fish can transmit the virus to others. Until this is confirmed, it would be prudent not to cohabit naïve fish with survivors of IHN.

Based on the findings from this study, if the disease history of a group of fish is unknown, the most reliable method of determining whether that population of fish has undergone an IHN outbreak is to test fish for virusspecific antibodies. Despite differences in fish health and environmental conditions, antibodies were consistently detected long after the virus was no longer detectable in the fish. Furthermore, serum samples can be obtained non-lethally.

Acknowledgements. We thank the Pacific Biological Station for providing the facility for this research, the University of Saskachewan, Saskatoon, Saskatchewan, Canada, for providing the PhD stipend for S.S., and W. Chalmers for his editorial comments.

\section{LITERATURE CITED}

Almendras FE, Fuentealba IC (1997) Salmonid rickettsial septicemia caused by Piscirickettsial salmonis: a review. Dis Aquat Org 29:137-144

Amend DF (1975) Detection and transmission of infectious hematopoietic necrosisvirus in rainbow trout. J Wildl Dis 11:471-478

Amend DF, Smith L (1974) Pathophysiology of infectious hematopoietic necrosis virus disease in rainbow trout (Salmo gairdneri): early changes in blood and aspects of the immune response after injection of IHN virus. J Fish Res Board Can 31:1371-1378

Amos KH, Hopper KA, LeVander L (1989) Absence of infectious hematopoietic necrosis virus in adult sockeye salmon. J Aquat Anim Health 1:281-283

Armstrong R, Roninson JR, Rymes C, Needham T (1993) Infectious hematopoietic necrosis virus in Atlantic salmon in British Columbia. Can Vet J 34:312-313

Bootland LM, Leong JC (1999) Infectious haematopoietic 
necrosis virus, Chap 2. In: Woo PTK, Bruno DW (eds) Fish diseases and disorders, Vol 3. Viral, bacterial and fungal infections. $\mathrm{CAB}$ International Publishing, Cambridge, p 57-121

Daniel WW (1987) Biostatistics: a foundation for analysis in the health sciences, 5th edn. John Wiley \& Sons, New York

Drolet BS, Chiou PP, Heidel J, Leong JC (1995) Detection of truncated virus particles in a persistent RNA virus infection in vivo. J Virol 69:2140-2147

Hattenburger-Baudouy AM, Danton M, Merle G, Torchy C, de Kinkelin P (1989) Serological evidence of infectious hematopoietic necrosis in rainbow trout from a french outbreak of disease. J Aquat Anim Health 1:126-134

Hattenburger-Baudouy AM, Danton M, Merle G, de Kinkelin $P$ (1995) Epidemmiology de la necrose hemotapoietique infectieuse (NHI) des salmonides en France: suivi de l'infection naturelle par des techiniques virologiques et serologiques et tentative d'eradication. Vet Res 26: 256-275

Kent ML, Dungan CF, Elston RA, Holt RA (1988) Cytophaga sp. (Cytophagales) infection in seawater pen-reared Atlantic salmon Salmo salar. Dis Aquat Org 4:173-179

LaPatra SE (1996) The use of serological techniques for virus surveillance and certification of finfish. Annu Rev Fish Dis 6:15-28

LaPatra SE, Turner T, Lauda KA, Jones GR, Walker S (1993). Characterization of the humoral response of rainbow trout to infectious hematopoietic necrosis virus. J Aquat Anim Health 5:165-171

Martin SW, Meek AH, Willeberg P (1987) Veterinary epidemiology principles and methods. Iowa State University Press, Ames

Mulcahy D, Jenes CK, Pascho R (1984) Appearance and quantification of infectious hematopoietic necrosis virus in

Editorial responsibility: Jo-Ann Leong,

Corvallis, Oregon, USA female sockeye salmon (Oncorhynchus nerka) during their spawning migration. Arch Virol 80:171-181

Ristow SS, de Avila J, LaPatra SE, Lauda K (1993) Detection and characterization of rainbow trout antibody against infectious hematopoietic necrosis virus. Dis Aquat Org 15: 109-114

Santner TJ, Duffy DE (1980) Statistical analysis of discrete data. Springer-Verlag, New York

St-Hilaire S (2000) The epidemiology of infectious hematopoietic necrosis disease in net-pen reared Atlantic salmon in British Columbia, Canada. PhD thesis, University of Guelph, Guelph, Ontario

Thorburn MA (1996) Apparent prevalence of fish pathogens in asymptomatic salmonid populations and its effect on misclassifying populations infection status. J Aquat Anim Health 8:271-277

Toranzo AE, Hetrick FM (1982) Comparative stability of two salmonid viruses and poliovirus in fresh, estuarine and marine waters. J Fish Dis 5:223-231

Traxler GS, Roome JR, Kent ML (1993) Transmission of infectious hematopoietic necrosis virus in salt water. Dis Aquat Org 16:111-114

Traxler GS, Roome JR, Lauda KA, LaPatra S (1997) Appearance of infectious hematopoietic necrosis virus (IHNV) and neutralizing antibodies in sockeye salmon Oncorhynchus nerka during their migration and maturation period. Dis Aquat Org 28:31-38

Vestergaard-Jørgensen PE, Olsen NJ, Lorenzen N, Winton JR, Ristow SS (1991) Infectious hematopoietic necrosis (IHN) and viral hemorrhagic septicemia (VHS): detection of trout antibodies to the causative viruses by means of plaque neutralization, immunofluorescence and enzymelinked immunosorbent assay. J Aquat Anim Health 3: $100-108$

Submitted: February 5, 2001; Accepted: May 8, 2001

Proofs received from author(s): August 6, 2001 